\title{
The impact of information and communication technology and internal market orientation blending on organisational performance in small and medium enterprises
}

ICT and IMO impact on SME performance

\section{Sergey Kazakov}

Graduate School of Business, Higher School of Economics, National Research University, Moskva, Russian Federation and Economics and Business Administration PhD Programme at University of Málaga, Málaga, Spain

José L. Ruiz-Alba

University of Westminster, London, UK, and

María M. Muñoz

Facultad de Ciencias Economicas y Empresariales, Universidad de Malaga,

$$
\text { Malaga, Spain }
$$

\begin{abstract}
Purpose - The present study examines the concept of internal market orientation (IMO) and its effects on organisational performance comprising job satisfaction and employees' loyalty in the small and medium enterprises (SMEs) research context. Rooted in administrative theory, human relations theory, conventional theories of IMO and internal marketing, this study develops a novel iIMO theoretical framework that evinces the proliferation of ICTs in SMEs.

Design/methodology/approach - The proposed concept was empirically investigated by means of surveying $316 \mathrm{SME}$ employees with the application of a multi-stage sampling procedure.

Findings - Research findings confirmed the viability of the ICT-supported iIMO framework, its positive effects on SMEs' organisational performance, and exhibited ample empirical evidence for the proficiency of the iIMO concept and its suitability for operationalisation by SMEs.

Originality/value - This study introduces ICTs as a novel IMO dimension which considers the undergoing holistic digitalisation of businesses. In addition, the present research posits the plausibility and confirms the benefits that arise following iIMO implementation in SMEs.
\end{abstract}

Keywords SMEs, Job satisfaction, Market orientation, Organisational performance, Internal marketing,

Internal market orientation

Paper type Research paper

\section{Introduction}

The notion of internal market orientation (IMO) implies the deployment and application of the marketing paradigm in the settings intrinsic to the organisation (Modi and Sahi, 2018). IMO is

(C) Sergey Kazakov, José L. Ruiz-Alba and María M. Muñoz. Published in European Journal of Management and Business Economics. Published by Emerald Publishing Limited. This article is published under the Creative Commons Attribution (CC BY 4.0) licence. Anyone may reproduce, distribute, translate and create derivative works of this article (for both commercial and non-commercial purposes), subject to full attribution to the original publication and authors. The full terms of this licence may be seen at http://creativecommons.org/licences/by/4.0/legalcode

Received 15 April 2020 Revised 5 September 2020 13 October 2020 Accepted 8 November 2020 
EJMBE 30,2 a nexus of two influential concepts. First, it is rooted in the concept of conventional internal marketing, which suggests organisations consider their employees as internal customers (Sasser and Arbeit, 1976). Employee-oriented implementation of marketing tools benefits the organisation by increasing job satisfaction and leads to improvements in organisational performance (Piercy, 1995). Second, IMO hinges on the market orientation framework, introduced to the academic domain by two independent studies that sparked the onset of the seminal research stream (Narver and Slater, 1990; Kohli and Jaworski, 1990).

In its essence, IMO focuses solely on company employees who are valued similarly to the firm's ordinary customers (Boukis, 2019). This emphasis makes IMO different from a broader approach specific to internal marketing that also encompasses its stakeholders, third-party suppliers and other actors in the layer between internal and external environments of the organisation (Hult et al., 2011). Unlike internal marketing, IMO benefits from the market orientation capabilities that make its implementation more efficient (Lings, 2004).

Until very recently, IMO has been themed by a plethora of studies. Literature indicates research vectoring towards IMO conceptualisation by determination of the organisational behaviours constituting it (Ruizalba and Vallespín, 2014). Another prolific stream of research embraces studies that explicate the outcomes of IMO implementation. IMO outcomes, or consequences, habitually comprise multilateral facets of the organisational and business performance. In this vein, researchers determined positive effects from organisational performance metrics as a result of IMO implementation (Yu et al., 2019).

Organisational performance is an area of prime concern for organisations when they seek effective approaches to allocating their resources, creating customer value, developing and implementing strategies because these efforts may ensure their profitability (Peteraf, 1993). SMEs are not an exception in this regard (Liu and Yang, 2020). These organisations create jobs, generate innovations and contribute to GDP in many countries (Rincón Díaz and Albors Garrigós, 2017). SMEs are often family businesses (Maseda et al., 2019). The social and economic significance of SMEs is well-conceived in academia as they have received a prolific amount of scrutiny in the literature (Noori et al., 2017).

IMO studies have examined various contexts, including service industries, emerging markets or large firms (Kaur Sahi et al., 2013; Ruizalba et al., 2014; Cerqueira et al., 2018). The research settings for SMEs, however, have not received ample consideration from academia to date. Conversely, the SMEs' market orientation, in its extrinsic sense, has been the subject of many studies. In this vein, prior studies have examined the capability of SMEs to adopt a market orientation, and its coherence with SMEs' entrepreneurship and innovativeness. These studies confirmed that market orientation improves SMEs' business performance (Raju et al., 2011; Länsiluoto et al., 2019).

Furthermore, we noted a gap in the extant research pertaining to the limited comprehension of latent drivers behind market-oriented organisational behaviours that have significant effects on SMEs' business performance. We argue that, besides the power of entrepreneurship, there must be essential elements of the organisational performance that gear SMEs towards innovativeness and market orientation. According to the literature, job satisfaction and employee loyalty generate these SMEs behaviours (Yu et al., 2019). We reckon them to be a product that results from IMO implementation.

Next, the canonical IMO literature has a paucity in the examination of technological drivers that enforce IMO implementation. Until recently, an expanding digitalisation of businesses has not received ample consideration by academia in the context of IMO with very few exceptions (Kazakov, 2019). The digitalisation of businesses is enabled by Information and Communications Technologies (ICT) that imply the combination of unified communications (chat boards, instant messaging, video calls and conferencing, cloud computing, etc.) with a hardware/software applications essential for data generation, accumulation, processing, and distribution (Riemer and Taing, 2009). ICT represent a contemporary platform for executing 
managerial processes and improve business performance in SMEs (Karakara and Osabuohien, 2020). IMO is relevant to the managerial process thereby, it is important for the theory to address ICT incorporation in IMO antecedents and thus to build comprehension of holistic IMO digitalisation in the setting of SMEs.

An amassed body of research points to several competitive advantages implicit in SMEs in comparison with bigger firms, including their flexibility, organisational resilience, readiness for new technologies, and adoption of advanced human resource management concepts (Cuéllar-Molina et al., 2019). We anticipate that IMO can be successfully adopted by SMEs and may improve their employees' job satisfaction and loyalty utterly shifting SMEs organisational performance. Hence, in accord with the above logic, we pose the purpose of this study that is to develop a theoretical framework that conceptualises ICT-driven IMO implementation in SME settings. This purpose determines our research objectives including (1) discernment of organisational behaviours that initiate IMO in SMEs in grounded in the conventional theory of internal market orientation; (2) corroboration of the IMO implementation effects following its reinforcement by ICT, and (3) confirmation of IMO implementation auspicious consequences on organisational performance in SMEs.

The delineated purpose and research objectives determine the sequential logic of furthering our research. First, we revisit and scrutinise the conventional theoretical approaches to IMO and suggest a concept compatible with the nature of SME. Second, we argue for the importance of embedding ICT into the $i \mathrm{IMO}$ framework because digitisation increases the quality and speed of managerial processes (Raissi and Matoussi, 2020). Third, grounded in the extant theory, we formulate research hypotheses and propose a research method for their verification. At last, we utilise empirical data retrieved from $316 \mathrm{SME}$ employees in Moscow, Russia, to validate hypotheses, and, ultimately, the $i \mathrm{IMO}$ framework.

This paper further unfolds in a sequence of literature review, research methodology, findings and implications sections. The paper concludes with a summary of the completed research and recommendations for future researchers interested in the further $i \mathrm{IMO}$ examination in the context of SMEs.

\section{Literature review and development of hypotheses \\ 2.1 Internal marketing and market orientation}

As noted above, IMO originated in the concept of internal marketing. Sasser and Arbeit (1976) first suggested a firm to consider its employees as the "most important customer" and "jobs as its principal product" (p. 61). Berry (1981) further posited internal marketing as the means for value exchange between companies and employees. It was also documented that internal marketing improves conventional (external) marketing implementation by the organisation (Lings, 2000). Early studies on internal marketing merely examined its impact on job satisfaction and focused more on service industries (Varey, 1995). More recent literature discovered the influence of internal marketing on job satisfaction, which further activates employee loyalty (Tansuhaj et al., 1988). Other researchers argued for internal marketing impacts on job efficiency, employee performance, and customer-centric vision implicit for all employees in a firm (Rafiq and Ahmed, 1998). Further studies determined that internal marketing generates the conditions necessary for inter-departmental alignment and "changemanagement" activation (Piercy, 2009).

Simultaneously, according to the literature, internal marketing has received some criticism from academia. Researchers have pointed to its ambiguity, limitations, and selfcontradicting nature that infringe the smooth flow of HRM processes in the organisation (Hales, 1994). Several academics have perceived internal marketing as "purely academic", too broad, and unrealistic as it lacks an explication of its implementation (Pitt and Foreman, 1999). However, the critical research stream has neither insisted on the redundancy of internal 
EJMBE 30,2 marketing nor suggested that organisations abstain from its application but posited reasonable open questions to be addressed by researchers. Such questions were relevant to internal marketing development, its conceptual precision, and proper operationalisation in the organisation (Foreman and Money, 1995).

Internal marketing research gained momentum from the introduction and proliferation of the market orientation paradigm, which helped academia to get closer to tackling the abovenoted issues. Succinctly, market orientation implies activation of organisational behaviours, namely, market intelligence generation and dissemination, that establish a basis for responsive strategy development and execution (Kohli and Jaworski, 1990). Market orientation also helps companies to develop and maintain a strategic focus on customer orientation, competitor orientation, and inter-functional coordination in the organisation (Narver and Slater, 1990). Market orientation implementation produces effects on the company's functioning and eventually improves its performance (Lings and Greenley, 2009).

A convergence of internal marketing and market orientation gave rise to the term IMO, first coined by Mohrw-Jackson (1991). Until very recently, IMO studies have grown into a seminal and notable research stream in the marketing literature. In the next subsection, we examine the amassed research pertinent to the current state of IMO conceptualisation and develop a rationale for the research hypotheses.

\subsection{ICT application in SME operations}

Researchers have spotted an increasing influence of digitalisation and the application of ICT on SME's business efficiency and performance. Besides, SMEs actively utilise ICT because these technologies aid them in rivalling with bigger-sized businesses (AlBar and Hoque, 2019). SMEs profusely employ CRM, POS, desktop publishing, specialised industry-specific software and Internet solutions to support their routine operations. The recent research points to the growing scale of web-based intranet applications usage in SMEs for HR management purposes, including internal communications and employee engagement (Chertchom et al., 2019).

However, researchers have found several ICT adoption and dissemination issues in SMEs that mitigate the efficiency of technology internalisation. SMEs uniformly lack financial resources, expertise, and suitable solutions in ICT utilisation. Available ICT compatibility with specific SMEs tasks and routines is another notable barrier in technologies acceptance (AlBar and Hoque, 2019). Simultaneously, literature documented a generally faster SMEs' speed in digitalisation processes in comparison with larger organisations (Eze et al., 2019). Thereby, it suffices the necessary grounds to suggest and further examine a blending of ICT and IMO antecedent elements.

\section{3 iIMO theoretical framework}

According to Lings (2004), IMO inherited its essence from the behavioural concept of market orientation originally suggested by Kohli and Jaworski (1990). MARKOR structural elements of Intelligence Generation, Intelligence Dissemination, and Organisational Response imply internal behavioural components. Because of this, whereas MARKOR concept was initially developed for external market orientation, it can be replicated for the labour market intrinsic to the organisation. MKTOR model has a different organisational focus which is truly outward of the firm (Narver and Slater). In this sense, MKTOR constructs, especially Competitor Orientation, cannot be referred to as the unambiguous elements of IMO. Consequently, researchers posited a better suitability MARKOR framework demonstrates better compatibility with the crux and scope of IMO (Lings, 2004; Lings and Greenly, 2009; Boukis, 2019).

By implementing IMO, organisations generate intelligence from both internal and external labour environments. Then, intelligence is disseminated internally, so employees are 
aware of the matters relevant to their organisation. Simultaneously, managers benefit from data revealing the psychological climate in the organisation, employees' needs, and demands as this information is essential to developing responsive IMO strategies aimed at organisational performance (Lings and Greenley, 2009).

A prominent amount of recent research has focused on the determination and measurement of IMO antecedents and consequences in various contexts (Gounaris, 2006; Ruizalba et al., 2014). However, little is understood about IMO conceptualisation in SMEs. These particular settings have enticed researchers who have examined the external market orientation capabilities of SMEs (Länsiluoto et al., 2019). Surprisingly, the literature is more committed to the bigger firms whilst showing the unavailability of empirical studies that conceptually scrutinise IMO in SMEs. These organisations have social and economic significance; thus, their performance is essential, and thereby, it is essential to shed more light on the peculiarities of IMO implementation in this particular context. The proposed $i \mathrm{IMO}$ theoretical model is depicted in Figure 1. It is prefixed with an " $"$ " to indicate its digital crux following the ICT and IMO antecedents blending.

\subsection{Antecedents of iIMO}

The $i \mathrm{IMO}$ antecedents denote three organisational behaviours, which are essential for its implementation in SMEs. According to administrative theory, these behaviours should be sequentially applied by the organisation (Fayol, 1918). External market orientation literature corroborates this order of execution (Kohli and Jaworski, 1990). In this regard, $i$ IMO implementation commences with working environment intelligence that generates the knowledge and proper perception of value exchange in the organisation (Lings, 2004; Gounaris, 2006). This particular $i \mathrm{IMO}$ construct is constituted by internal labour market research, and by personnel segmentation. The latter is a useful technique to identify groups of employees with similar wants and needs (Ruizalba et al., 2014).

The organisation would benefit from the dissemination of the collected data and information received from the intelligence (Tortosa et al., 2009). These processes are facilitated by the internal communications embedded in the $i \mathrm{IMO}$ concept. Additionally, internal communications imply informal encounters between managers and employees. According to human relations theory, such contacts build relationships that are motivational factors for employees (Mayo, 1933).

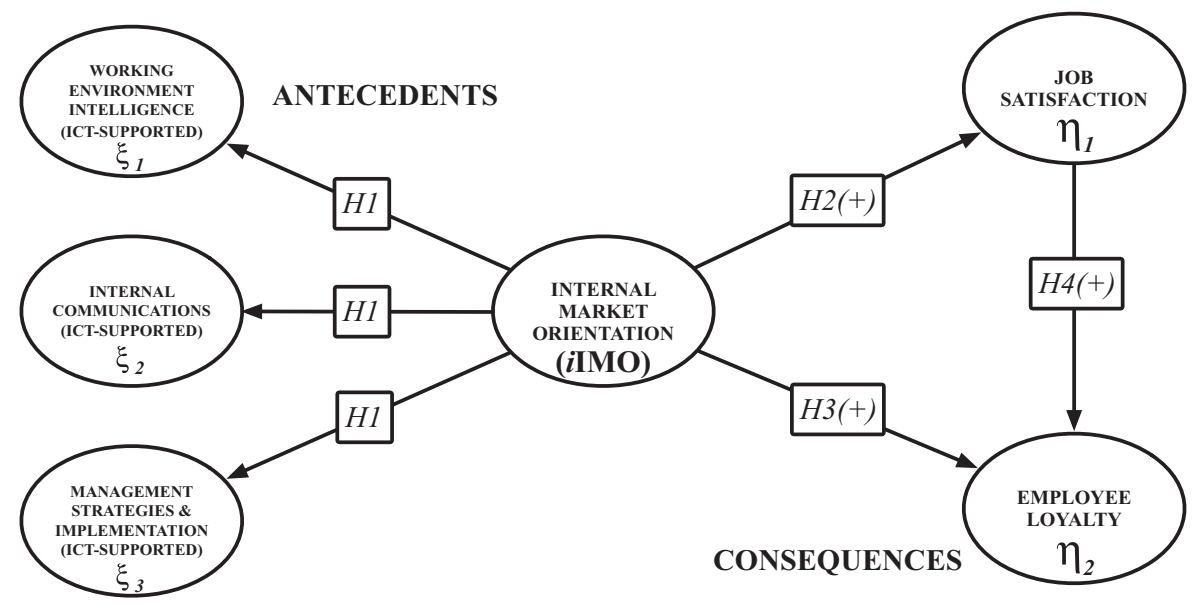

ICT and IMO impact on SME performance
Figure 1. $i \mathrm{IMO}$ theoretical model 
EJMBE 30,2

The intelligence dissemination helps managers to obtain an unambiguous and unbiased comprehension of the firms' internal environment adequacy to the external labour market (Gounaris, 2008). Furthermore, managers receive guidance and a rationale for responsive strategies, planning and execution (Kaur Sahi et al., 2013). In the $i \mathrm{IMO}$ framework, these strategies are developed to activate managers' care of employees, personnel trainingdevelopment, and work-family balance (Ruizalba et al., 2016).

Earlier, we noted a role that ICT play in SMEs' management routine. ICT speed-up managerial processes execution, increase employee productivity and lead to organisational improvement (Ab Wahab et al., 2020). Accordingly, ICT is a proxy that enforces organisational behaviour elements essential to run iIMO implementation in SMEs. In this vein, we argue that the blend of ICT with above-delineated $i \mathrm{IMO}$ antecedents builds relevant grounds for $i \mathrm{IMO}$ implementation in SMEs, thus:

H1. Internal market orientation (iIMO) is enacted by digitalised organisational behaviours of working environment intelligence, internal communications, and management strategies implementation.

\section{5 iIMO effects on internal organisational performance}

Gauging the outcomes following IMO implementation has been a cornerstone research issue until very recently. In this regard, researchers have scoped numerous organisational performance metrics to measure the effects of IMO. Similarly to the internal marketing research stream, the gauging of job satisfaction has been typical in IMO studies (Tortosa et al., 2009; Modi and Sahi, 2018). Renowned in management academia, the job characteristics model depicts job satisfaction effects on an employee, including increasing productivity and reduction in absenteeism (Hackman and Oldham, 1975). Entwined with this proposition, Gounaris (2006, p. 438) posits that job satisfaction is a prime criterion of organisational performance. Hence, job satisfaction is an essential variable to consider in the proposed $i \mathrm{IMO}$ framework. On these grounds, we hypothesise that:

H2. $i \mathrm{IMO}$ produces a positive effect on employee job satisfaction in SMEs.

A notable array of studies has articulated job satisfaction with its outcomes. Prior research measured the direct and indirect effects of job satisfaction on the other internal or external facets of organisational performance (Chow et al., 2015). Concerning external performance items, researchers found that job satisfaction improves customer satisfaction, customer orientation, and service quality (Lings and Greenley, 2009; González-Porras et al., 2019). Other studies highlighted internal organisational performance items driven by job satisfaction that include employee motivation and job commitment (Ruizalba et al., 2014). We noted in the IMO literature, however, that the dimension of employee loyalty to her/his respective employing organisation has been overlooked. Employee loyalty has a significant role in the reduction of personnel churn rates (Mueller et al., 1992). Thus, it implies a significant criterion of organisational performance and should be investigated under the $i \mathrm{IMO}$ framework. Consequently, we argue that:

H3. $i \mathrm{IMO}$ produces a positive effect on employee loyalty to the employing SME.

By embedding employee loyalty, we introduce a dyad of "job satisfaction $\rightarrow$ employee loyalty" to the proposed $i \mathrm{IMO}$ concept. Such loyalty is an absolute consequence of internal marketing and determines its ultimate efficacy. Prior studies documented a significantly positive effect created by job satisfaction on employee loyalty (Matzler and Renzl, 2006). Thereby, the IMO theory will benefit from the verification of this effect in the SME context. Moreover, as previous research has neglected to examine the direct and indirect effects of IMO on employee loyalty, there is a chance to determine whether job satisfaction increases 
iIMO effects on employee loyalty in SMEs both directly or indirectly. In this study, we additionally assign job satisfaction as a mediator variable that conveys $i \mathrm{IMO}$ effects on employee loyalty in SMEs. In line with the above, we posit that:

H4. Employee job satisfaction reinforces the positive effect of iIMO on employee loyalty in SMEs.

\section{Research methodology}

\subsection{Scales and questionnaire development}

Under the purpose of the study, which concerned measurement of employee perceptions of $i \mathrm{IMO}$ and its outcomes, we decided that a survey was the most appropriate method for data collection. Researchers often face the dilemma of whether to develop a new questionnaire or use existing measures to assure survey quality (Biemer and Lyberg, 2003). In the domain of IMO studies, Gounaris (2006) suggested developing measurement and structural models grounded in prior reputable research. In this respect, the literature review is helpful for shaping an initial concept and retrieving a set of conventional constructs and measurement items. Then, the researcher may lean on personal experience, ideas, or intuition to draft an estimated conceptual model that may supplement the original items with new scales, measurements, latent variables, alternative liaisons between variables, and so on. If empirically confirmed, the developed concept may imply a theoretical contribution to the field (Hair et al., 2014).

By heeding these practical recommendations, we adapted a questionnaire from Ruizalba et al. (2014) to collect survey data. This questionnaire employed scales from notable studies that had previously investigated IMO in various settings (Lings, 2004; Gounaris, 2008). As we planned to examine the influence of ICT on $i$ IMO implementation in SMEs in this study, we adapted a suitable part of the Hanclova et al. (2015) questionnaire. Next, we established job satisfaction measurements grounded in Hartline and Ferrel (1996), and employee loyalty was measured based on Knox and Freeman (2006). Finally, we favoured the seven-point Likert ordinal metric scale for the developed questionnaire as recommended by the literature (Bendixen and Sandler, 1995).

As a result, the draft questionnaire contained 47 questions, 6 of which were relevant to descriptive statistics, whereas the remaining 41 questions implied $i \mathrm{IMO}$ measurement scales. The outer model shaped a structural nomological framework that contained twelve firstorder, three second-order, and three third-order latent factor constructs as depicted earlier (Figure 1). Before embarking on a study, the IMO literature recommends pretesting drafted models and questionnaires by following the Churchill (1979) research stratagem (Gounaris, 2006). It implies a two-step procedure, including individual in-depth expert interviews followed by a trial survey run with a small number of "dummy" participants.

In the course of the questionnaire pretesting, at first, we arranged ten personal interviews with experts knowledgeable in the present research field. This phase was essential to validate the relevance of the measurement items, latent constructs, and relationships between them, as suggested in the developed model. Aiming to secure a broader scope of research insights, we split the group into two subsamples that included five university professors and five practitioners. Following the discussions, four scholars and five practitioners pointed to low suitability of the personnel segmentation and redundancy of the training - development constructs for the SME setting. Besides this, experts gave several practical recommendations to improve the questionnaire. Considering these recommendations, we removed six measurement items from the drafted model and modified the questionnaire accordingly.

Next, the updated questionnaire underwent a pilot test to ensure the proper questions sequence and understandability for survey participants. We randomly selected $10 \mathrm{SME}$
ICT and IMO impact on SME performance 
EJMBE 30,2 employees who completed the survey forms under our observation. Resulting from this part of the pretest procedure, we made minor textual revisions and released a final questionnaire.

\subsection{Sample and data collection}

As SMEs acted the sampling frame for the study, their regular employees were appointed as singular sampling units for data collection. We used a multi-stage sampling procedure (Teddlie and $\mathrm{Yu}, 2007$ ). Adapted to our study, it included two steps. The first phase implied simple random sampling aimed at building a contact base for questionnaire distribution. This process included a selection of 1,500 local SMEs by using a random digits generator. The second phase involved homogeneous purposive sampling for survey participant recruitment. The chosen sampling technique is suitable for recruiting participants who share the same fixed attributes (Jupp, 2015). We established such attributes to include at least three years of full-time employment in a non-management position in an SME.

An online SMEs database served as a source for the sampling frame construction and aided in building a contact base for targeting potential survey participants. We cooperated with a third-party organisation that approached the randomly selected SMEs through e-mails. The circulated message explained to SMEs the benefits of participation, asked them to engage their employees in our survey, and provided a link to the online questionnaire. To ensure that all selected SMEs had received the first communication, the collaborator sent a follow-up letter two weeks after the first mailing.

It took two months to complete survey data collection. The initial dataset contained 369 ( $24.6 \%$ response rate) forms. We further screened the dataset for incomplete forms, response inconsistency and data outliers. This procedure secured a sample of $n=316$ (21\% rate) observations eligible for data analysis. Such a size of the sample suffices the application of the SEM procedure for the developed $i \mathrm{IMO}$ model consisting of 6 constructs and a communality value (that is "the average amount of variation among the measured/indicator variables explained by the measurement model" (Hair et al., 2014, p. 573)), equal to 0.6 as the literature suggests (Enders and Bandalos, 2001).

Table 1 illustrates data distributions for descriptive statistics that can provide comprehension of the SMEs sampled under this study.

\section{Results}

\subsection{Composite reliability, convergent and discriminant validity}

The developed $\imath \mathrm{IMO}$ theoretical framework implied a sophisticated blend of various variables and their complex relationships. Such complexity demanded a series of separate equations to explain the constitution of latent factors and causalities between the various variables. Thereby, our study required an appropriate analytical technique that could simultaneously scrutinise the concept and reveal essential statistical output relevant to the examined theory. The literature recommends an application of the SEM PLS procedure for this purpose (Hair et al., 2014). Prior IMO studies favoured the same statistical approach (Lings, 2004; Gounaris, 2008).

When applying SEM, first, we ensured the uniformity of manifest variables $\left(x_{n}\right)$ that constitute their respective exogenous $\left(\xi_{n}\right)$ or endogenous $\left(\eta_{n}\right)$ constructs. It was essential to confirm that these variables gauge the same factor to ensure their composite reliability (CR). The received $\mathrm{CR}$ values for model constructs exceeded the threshold of 0.7 ; thereby, the $i \mathrm{IMO}$ measurement scales conform to CR requirements model-wide. Second, as CR is required but not ample provision to ensure validity, the SEM procedure entails discriminant and convergent validity verification for both measurement and structural models. For such purposes, it is critical to assess additional validity indices, namely, average variance extracted (AVE), average shared squared variance (ASV) and maximum shared squared 


\begin{tabular}{|c|c|c|c|}
\hline Variables and labels & Count & $\%$ & and IIMO \\
\hline $\begin{array}{l}\text { Gender } \\
\text { - Female } \\
\text { - Male }\end{array}$ & $\begin{array}{l}167 \\
149\end{array}$ & $\begin{array}{l}53 \\
47\end{array}$ & performance \\
\hline $\begin{array}{l}\text { Position in the organisation } \\
\text { - Contracted full-time employee } \\
\text { - Business owner or partner } \\
\text { - Contracted top manager }\end{array}$ & $\begin{array}{r}190 \\
88 \\
38\end{array}$ & $\begin{array}{l}60 \\
28 \\
12\end{array}$ & 137 \\
\hline $\begin{array}{l}\text { Number of employees in the organisation } \\
\text { - More than } 50 \\
\text { - } 11 \text { up to } 50 \\
\text { - } 2 \text { up to } 10 \\
\text { - Self-employed registered business }\end{array}$ & $\begin{array}{r}65 \\
104 \\
125 \\
22\end{array}$ & $\begin{array}{r}20 \\
33 \\
40 \\
7\end{array}$ & \\
\hline $\begin{array}{l}\text { Approximate annual sales of the organisation } \\
\text { - Above } € 43 \text { million } \\
\text { - Up to } € 43 \text { million } \\
\text { - Up to } € 10 \text { million } \\
\text { - Up to } € 2 \text { million }\end{array}$ & $\begin{array}{r}12 \\
24 \\
61 \\
219\end{array}$ & $\begin{array}{r}4 \\
7 \\
19 \\
70\end{array}$ & \\
\hline $\begin{array}{l}\text { Industry of operation } \\
\text { - Corporate services } \\
\text { - Wholesale business } \\
\text { - Retail business } \\
\text { - Manufacturing and craftworks } \\
\text { - Consumer services } \\
\text { - Other }\end{array}$ & $\begin{array}{l}89 \\
58 \\
50 \\
44 \\
25 \\
50\end{array}$ & $\begin{array}{r}28 \\
18 \\
16 \\
14 \\
8 \\
16\end{array}$ & \\
\hline $\begin{array}{l}\text { Targeted customer types } \\
-\mathrm{B} 2 \mathrm{~B} \\
-\mathrm{B} 2 \mathrm{C} \\
-\mathrm{B} 2 \mathrm{~B} 2 \mathrm{C} \\
-\mathrm{B} 2 \mathrm{G}\end{array}$ & $\begin{array}{r}137 \\
82 \\
54 \\
43\end{array}$ & $\begin{array}{l}43 \\
26 \\
17 \\
14\end{array}$ & $\begin{array}{r}\text { Table } 1 . \\
\text { Descriptive statistics }\end{array}$ \\
\hline
\end{tabular}

variance (MSV) (Hair et al., 2014). Table 2 exhibits the results of the reliability and validity tests applied for the $i \mathrm{IMO}$ model. These tests unveiled that two first-order latent constructs, namely Personnel segmentation and Personnel training/development do not suffice the validity requirements, so we discarded them from the model.

Table 1 shows that the essential requisites [CR $>$ AVE, AVE $>$ MSV, AVE $>$ ASV (Hair et al., 2014, pp. 619, 631-633)] for $i \mathrm{IMO}$ model convergent and discriminant validity are present. Additionally, we examined covariation values between $\xi_{n}$ and $\eta_{n} i \mathrm{IMO}$ constructs. As all covariation values exceed 0.7 and are statistically significant $(\phi=0.000)$, they represent a supplementary pillar for the $i \mathrm{IMO}$ model's validity. Table 3 depicts a covariation matrix between $i \mathrm{IMO}$ model constructs.

Further analysis demonstrated the sufficient goodness-of-fit statistics of the $i$ IMO model $\left(\right.$ RMSEA $=0.072 ; \frac{\chi^{2}}{\mathrm{df}}=3.86$; $\mathrm{CFI}=0.86$; TLI $\left.=0.81\right)$. The obtained results of reliability, validity and goodness-of-fit analyses confirmed the relevancy of the $i$ IMO model and built a rationale for the following hypothesis testing that we delineate in the following subsections.

\section{2 iIMO antecedents validation}

Following the covariation matrix exhibited in Table 2, $i$ IMO highly covariates with its antecedents, which are also substantially interrelated (Table 2). This condition, along with 
EJMBE

30,2

\begin{tabular}{|c|c|c|c|c|c|c|}
\hline & Constructs & $\mathrm{CR}$ & AVE & ASV & MSV & $\begin{array}{c}\text { Cronbach's } \\
\alpha\end{array}$ \\
\hline \multicolumn{7}{|c|}{ iIMO antecedents } \\
\hline \multicolumn{7}{|c|}{ Measurement model (1st order) } \\
\hline$\xi_{1}$ & Working environment intelligence (ICT-supported) & & & & & \\
\hline$\xi_{11}$ & Personnel research (4 scales, $x_{n}$ ) & 0.71 & 0.58 & 0.25 & 0.20 & 0.87 \\
\hline$\xi_{12}$ & Labour market research ( 3 scales, $x_{n}$ ) & 0.71 & 0.51 & 0.21 & 0.37 & 0.84 \\
\hline$\xi_{13}$ & ICT in personnel research ( 3 scales, $x_{n}$ ) & 0.70 & 0.52 & 0.28 & 0.40 & 0.83 \\
\hline$\xi_{3}$ & \multicolumn{6}{|l|}{ Management strategies and implementation (ICT-supported) } \\
\hline$\xi_{31}$ & Management concern and care (5 scales, $x_{n}$ ) & 0.77 & 0.66 & 0.27 & 0.31 & 0.89 \\
\hline$\xi_{32}$ & Work-life balance ( 3 scales, $x_{n}$ ) & 0.74 & 0.58 & 0.27 & 0.45 & 0.86 \\
\hline$\xi_{33}$ & $\begin{array}{l}\text { Remuneration policies: salary and incentives ( } 3 \text { scales, } \\
\left.x_{n}\right)\end{array}$ & 0.74 & 0.56 & 0.21 & 0.12 & 0.84 \\
\hline$\xi_{34}$ & Job essence and functions ( 3 scales, $x_{n}$ ) & 0.76 & 0.59 & 0.32 & 0.20 & 0.87 \\
\hline$\xi_{35}$ & $\begin{array}{l}\text { ICT in management strategies and implementation ( } 3 \\
\left.\text { scales, } x_{n}\right)\end{array}$ & 0.75 & 0.66 & 0.28 & 0.25 & 0.79 \\
\hline \multicolumn{7}{|c|}{ Measurement model (2st order) } \\
\hline$\xi_{1}$ & $\begin{array}{l}\text { Working environment intelligence (ICT-supported) ( } 3 \\
\left.\text { first-order constructs, } \xi_{1 n}\right)\end{array}$ & 0.78 & 0.73 & 0.38 & 0.45 & 0.96 \\
\hline$\xi_{2}$ & Internal communications (ICT-supported) ( 7 scales, $\left.x_{n}\right)$ & 0.79 & 0.54 & 0.34 & 0.45 & 0.94 \\
\hline$\xi_{3}$ & $\begin{array}{l}\text { Management strategies and implementation (ICT- } \\
\left.\text { supported) (5 first-order constructs, } \xi_{3 n}\right)\end{array}$ & 0.79 & 0.58 & 0.40 & 0.45 & 0.90 \\
\hline$i \mathrm{IMO}$ & $i \mathrm{IMO}$ antecedents (structural model) & 0.79 & 0.66 & & & 0.92 \\
\hline \multicolumn{7}{|c|}{ iIMO consequences (measurement model) } \\
\hline$\eta_{1}$ & Job satisfaction (3 scales, $\left.y_{n}\right)$ & 0.73 & 0.56 & 0.34 & 0.20 & 0.83 \\
\hline$\eta_{2}$ & Employee loyalty (4 scales, $y_{n}$ ) & 0.79 & 0.66 & 0.40 & 0.20 & 0.83 \\
\hline
\end{tabular}

Table 2.

iIMO composite reliability, convergent and discriminant validity tests

\begin{tabular}{|c|c|c|c|c|c|c|}
\hline & $\begin{array}{c}\text { Working } \\
\text { environment } \\
\text { intelligence } \\
\text { (ICT- } \\
\text { supported) } \\
\left(\xi_{1}\right) \\
\end{array}$ & $\begin{array}{c}\text { Internal } \\
\text { communications } \\
\text { (ICT-supported) } \\
\left(\xi_{2}\right) \\
\end{array}$ & $\begin{array}{c}\text { Management } \\
\text { strategies and } \\
\text { implementation } \\
\text { (ICT-supported) } \\
\left(\xi_{3}\right) \\
\end{array}$ & iIMO & $\begin{array}{c}\text { Job } \\
\text { satisfaction } \\
\left(\eta_{1}\right)\end{array}$ & $\begin{array}{c}\text { Employee } \\
\text { loyalty } \\
\left(\eta_{2}\right)\end{array}$ \\
\hline $\begin{array}{l}\text { Working } \\
\text { environment } \\
\text { intelligence (ICT- } \\
\text { supported) }\left(\xi_{1}\right)\end{array}$ & 1 & & & & & \\
\hline $\begin{array}{l}\text { Internal } \\
\text { communications } \\
\text { (ICT-supported) } \\
\left(\xi_{2}\right)\end{array}$ & 0.85 & 1 & & & & \\
\hline $\begin{array}{l}\text { Management } \\
\text { strategies and } \\
\text { implementation } \\
\text { (ICT-supported) } \\
\left(\xi_{3}\right)\end{array}$ & 0.86 & 0.71 & 1 & & & \\
\hline iIMO & 0.92 & 0.85 & 0.86 & 1 & & \\
\hline $\begin{array}{l}\text { Job satisfaction } \\
\left(\eta_{1}\right)\end{array}$ & 0.92 & 0.74 & 0.71 & 0.88 & 1 & \\
\hline $\begin{array}{l}\text { Employee } \\
\text { loyalty }\left(\eta_{2}\right)\end{array}$ & 0.85 & 0.72 & 0.73 & 0.81 & 0.90 & 1 \\
\hline
\end{tabular}

Table 3.

$i$ IMO model constructs covariation matrix

Employee
loyalty $\left(\eta_{2}\right)$ 
statistically significant $\chi^{2}=1028.98$ pertinent to the inner model, generates an initial inference that the prior assumptions of the $\mathrm{H} 1$ on the $i \mathrm{IMO}$ framework were correct. Nevertheless, H1 required a more robust technique for verification. Hair et al. (2014) indicated that CFA is a perfect choice to examine and affirm theoretical models that a researcher develops a priori. In this regard, we ran CFA on the structural model, which links $i \mathrm{IMO}$ with its antecedents $\xi_{1}, \xi_{2}, \xi_{3}$. CFA unveiled the reasonable $(\lambda \geq 0.5)$ and statistically significant $(\phi=0.000)$ values of factor loadings intrinsic to all three $i \mathrm{IMO}$ antecedent constructs $\left(\lambda_{\xi 1 \leftarrow i \mathrm{IMO}}=0.92 ; \lambda_{\xi 2 \leftarrow i \mathrm{IMO}}=0.67 ; \lambda_{\xi 3 \leftarrow i \mathrm{IMO}}=0.78\right)$. This finding indicates that ICT-supported working environment intelligence, internal communications, management strategies and implementation jointly constitute $i \mathrm{IMO}$. Thereby, H1 is confirmed.

\section{3 iIMO effects on job satisfaction and employee loyalty}

As noted above, SEM PLS has been credited for its versatility as it makes this method quite suitable for advanced multivariate analysis (Westland, 2015). In addition to simultaneous CFA and covariation computation, SEM is capable of estimating structural parameters $(\gamma)$ to examine causal links between constructs $\xi_{n}, \eta_{n}$. This estimation is also referred to as path analysis in SEM terminology, whereas structural causal estimate value is similar to the regression coefficient (Hair et al., 2014). As this study involved scrutiny of causalities between $i \mathrm{IMO}$ and its $\eta_{n}$ consequences, we employed path analysis to test the remaining hypotheses. Covariation matrix (Table 2) provided path analysis application support as covariation values demonstrated a high degree of covariation. Table 4 below presents the consolidated results retrieved from the $\mathrm{H} 2-\mathrm{H} 4$ tests.

Table 3 indicates significant direct $i \mathrm{IMO}$ effects on job satisfaction $\left(\gamma_{i \mathrm{IMO}} \rightarrow \eta 1=0.81\right.$, $p=0.000)$ and moderate positive influence on employee loyalty $\left(\gamma_{i \mathrm{IMO}} \rightarrow \eta 2=0.38, p=0.000\right)$. Estimated indirect $i \mathrm{IMO}$ effects on $\eta_{2}$ via $\eta_{1}$ are also moderately positive resulting from the application of two computation techniques employing either path or covariation coefficients $\left(\gamma_{i \mathrm{IMO} \rightarrow \eta 1} \times \beta_{\eta 1 \rightarrow \eta 2}=0.36 ; \gamma_{i \mathrm{IMO} \rightarrow \eta 1} \times \varphi_{i \mathrm{IMO} \rightarrow \eta 2}=0.65\right)$. These outcomes, thereby, support $\mathrm{H} 2$ and H3. Likewise, following a gauged path coefficient value, which is positive and statistically significant, $\mathrm{H} 4$ is supported $\left(\beta_{\eta 1} \rightarrow \eta 2=0.44, p=0.000\right)$. This result posits that $i \mathrm{IMO}$-driven job satisfaction positively influences employee loyalty to an employing SME organisation.

\subsection{Measurement of IIMO antecedents' direct and indirect effects}

The results obtained so far show that working environment intelligence $\left(\xi_{1}\right)$, internal communication $\left(\xi_{2}\right)$ and management strategies implementation $\left(\xi_{3}\right)$ are three antecedents of $i \mathrm{IMO}$, that is, they are three factors that directly influence $i \mathrm{IMO}$. Mathematically, we can express these dependencies as follows:

$$
i \mathrm{IMO}=f_{1}\left(\xi_{1}, \xi_{2}, \xi_{3}\right) ;
$$

where $\xi_{1}, \xi_{2}, \xi_{3}$ represent working environment intelligence, internal communication and management strategies implementation, respectively. In turn, iIMO influences job satisfaction, which can be expressed in the form of as follows:

\begin{tabular}{llccccc}
\hline & Research hypotheses & $\gamma_{\text {std }}$ & $\beta_{\text {std }}$ & $z$ & $p>|z|$ & Result \\
\hline H2 & $i$ IMO $\rightarrow$ Job satisfaction $\left(\eta_{1}\right)$ & 0.81 & - & 3.03 & 0.000 & accepted \\
H3 & $i$ IMO $\rightarrow$ Employee loyalty $\left(\eta_{2}\right)$ & 0.38 & - & 3.87 & 0.000 & accepted \\
H4 & Job satisfaction $\left(\eta_{1}\right) \rightarrow$ Employee loyalty $\left(\eta_{2}\right)$ & - & 0.44 & 3.96 & 0.000 & accepted
\end{tabular}

Table 4 . $i$ IMO effects on organisational performance (H2H4 tests) 
EJMBE

30,2

140

$$
\eta_{1}=f_{2}(i \mathrm{IMO})
$$

IMO also influences employee loyalty, but this output is influenced by $i \mathrm{IMO}$ and job satisfaction:

$$
\eta_{2}=f_{3}\left(i \mathrm{IMO}, \eta_{1}\right)=f_{3}\left(i \mathrm{IMO}, f_{2}(i \mathrm{IMO})\right)
$$

The variation in any of these three inputs affects, therefore, the two outputs, but it is worth wondering which of them affects more. Given that the results have been obtained by employing the technique of structural equations, the measurement must be carried out, necessarily, through the variable $i \mathrm{IMO}$, with which we will have to measure a two-stage "chain reaction": first, IMO reacts directly to the change in the input; second, the output reacts to the change in IMO. Mathematically, this two-stage reaction is measured through the chain rule, an important mathematical Calculus rule (see Hammond and Sydsaeter, 2012) with which this "chain reaction" is obtained. To gauge it, we employ the concept of the partial derivative, which measures the variation of one variable (one $i \mathrm{IMO}$ consequence in our case), before an infinitesimal (very small) variation of another (in our case, it refers to the $i \mathrm{IMO}$ antecedent).

These interrelations can be delineated using the following dependence tree (Figure 2).

In the case of job satisfaction, a change in one of the inputs will lead to a change in IMO and this, in turn, implies a change in job satisfaction. By application of the chain rule (Hammond and Sydsaeter, 2012), the entire iIMO antecedent effect can be exhibited as follows:

$$
\begin{aligned}
& \frac{\partial \eta_{1}\left(\xi_{1}, \xi_{2}, \xi_{3}\right)}{\partial \xi_{1}}=\frac{d \eta_{1}(i \mathrm{IMO})}{d i \mathrm{IMO}} \cdot \frac{\partial i \mathrm{IMO}\left(\xi_{1}, \xi_{2}, \xi_{3}\right)}{\partial \xi_{1}} \cong 0.81 \cdot 0.92=0.75 \\
& \frac{\partial \eta_{1}\left(\xi_{1}, \xi_{2}, \xi_{3}\right)}{\partial \xi_{2}}=\frac{d \eta_{1}(i \mathrm{IMO})}{d i \mathrm{IMO}} \cdot \frac{\partial i \mathrm{IMO}\left(\xi_{1}, \xi_{2}, \xi_{3}\right)}{\partial \xi_{2}} \cong 0.81 \cdot 0.67=0.54
\end{aligned}
$$

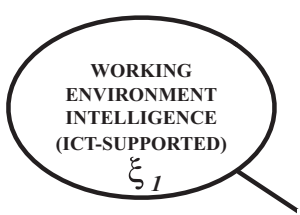

Figure 2.

$i \mathrm{IMO}$ antecedents and job satisfaction dependence tree

0.92

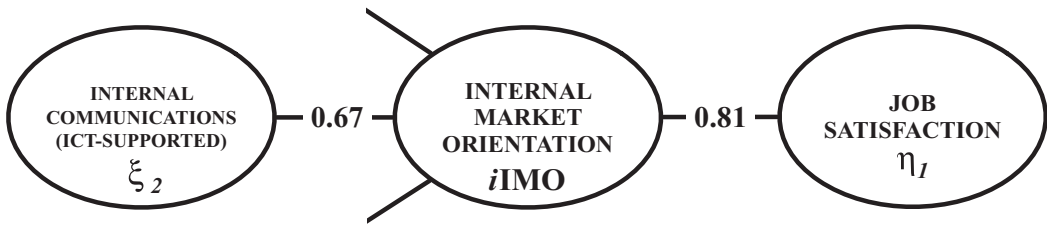

0.78

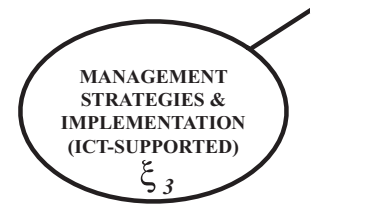




$$
\frac{\partial \eta_{1}\left(\xi_{1}, \xi_{2}, \xi_{3}\right)}{\partial \xi_{3}}=\frac{d \eta_{1}(i \mathrm{IMO})}{d i \mathrm{IMO}} \cdot \frac{\partial i \mathrm{IMO}\left(\xi_{1}, \xi_{2}, \xi_{3}\right)}{\partial \xi_{3}} \cong 0.81 \cdot 0.78=0.63
$$

In this case, the final effect of an infinitesimal change in each $i \mathrm{IMO}$ antecedent over job satisfaction is proportional $(81 \%)$ to the effect over $i \mathrm{IMO}$. Nevertheless, the effect of a change in one $i \mathrm{IMO}$ antecedent over employee loyalty is not proportional to the effect over the $i \mathrm{IMO}$, due to the influence of job satisfaction on loyalty. Consequently, the application of the chain rule is a bit more complex, but it clearly reflects the importance of the influence of job impact on SME performance satisfaction on loyalty:

$$
\begin{aligned}
\frac{\partial \eta_{2}\left(\xi_{1}, \xi_{2}, \xi_{3}\right)}{\partial \xi_{1}} & =\frac{\partial \eta_{2}(i \mathrm{IMO})}{\partial i \mathrm{IMO}} \cdot \frac{\partial i \mathrm{IMO}\left(\xi_{1}, \xi_{2}, \xi_{3}\right)}{\partial \xi_{1}}+\frac{\partial \eta_{2}(i \mathrm{IMO})}{\partial \eta_{1}} \frac{\partial \eta_{1}\left(\xi_{1}, \xi_{2}, \xi_{3}\right)}{\partial \xi_{1}} \cong 0.38 \cdot 0.92 \\
& +0.44 \cdot 0.75=1.07 \\
\frac{\partial \eta_{2}\left(\xi_{1}, \xi_{2}, \xi_{3}\right)}{\partial \xi_{2}} & =\frac{\partial \eta_{2}(i \mathrm{IMO})}{\partial i \mathrm{IMO}} \cdot \frac{\partial i \mathrm{IMO}\left(\xi_{1}, \xi_{2}, \xi_{3}\right)}{\partial \xi_{2}}+\frac{\partial \eta_{2}(i \mathrm{IMO})}{\partial \eta_{1}} \frac{\partial \eta_{1}\left(\xi_{1}, \xi_{2}, \xi_{3}\right)}{\partial \xi_{2}} \cong 0.38 \cdot 0.67 \\
& +0.44 \cdot 0.54=0.78 \\
\frac{\partial \eta_{2}\left(\xi_{1}, \xi_{2}, \xi_{3}\right)}{\partial \xi_{3}} & =\frac{\partial \eta_{2}(i \mathrm{IMO})}{\partial i \mathrm{IMO}} \cdot \frac{\partial i \mathrm{IMO}\left(\xi_{1}, \xi_{2}, \xi_{3}\right)}{\partial \xi_{3}}+\frac{\partial \eta_{2}(i \mathrm{IMO})}{\partial \eta_{1}} \frac{\partial \eta_{1}\left(\xi_{1}, \xi_{2}, \xi_{3}\right)}{\partial \xi_{3}} \cong 0.38 \cdot 0.78 \\
& +0.44 \cdot 0.63=0.91
\end{aligned}
$$

Given that, in the structural equation models, the underlying relationship between the variables is linear, we can interpret this derivative by the following increments:

$$
\begin{aligned}
& \Delta \eta_{1} \cong 0.75 \cdot \Delta \xi_{1}, \quad \Delta \eta_{1} \cong 0.54 \cdot \Delta \xi_{2}, \quad \Delta \eta_{1} \cong 0.63 \cdot \Delta \xi_{3} \\
& \Delta \eta_{2} \cong 1.07 \cdot \Delta \xi_{1}, \quad \Delta \eta_{2} \cong 0.78 \cdot \Delta \xi_{2}, \quad \Delta \eta_{2} \cong 0.91 \cdot \Delta \xi_{3}
\end{aligned}
$$

The entire $i \mathrm{IMO}$ antecedent effect can be exhibited as follows (Figure 3):

With these results, we can draw two supplementary conclusions. First, the effect of an infinitesimal change in any of the three inputs on employee loyalty is higher than that on the job satisfaction, due to the chain effect generated by influencing job satisfaction on employee loyalty. In this sense, when measuring the total effect of each $i \mathrm{IMO}$ antecedent on its consequences, it is essential to carry out the analysis through the chain rule, taking into account direct and indirect dependency relationships. This analysis unveils that the $i \mathrm{IMO}$ effect on job satisfaction is higher than on employee loyalty ( $81 \%$ vs. $38 \%)$. However, this effect is given through the $i \mathrm{IMO}$ consequences, and this effect must be measured globally; also, researchers have to take into account the functional relationships derived from the application of the SEM technique.

Second, our study determined the $i \mathrm{IMO}$ antecedent construct with the most significant impact on organisational performance. It is working environment intelligence, followed by management strategies implementation, with internal communication being the least influential, both in terms of job satisfaction and loyalty. This impact is measured by the variation in one of the $i \mathrm{IMO}$ antecedents and without taking into account the cost of each antecedent, something that should also be considered when designing a company strategy. We discuss this particular finding and other obtained research results in the next section of the present paper. 
EJMBE

30,2

142
Figure 3.

$i \mathrm{IMO}$ antecedents' direct and indirect effects on organisational performance

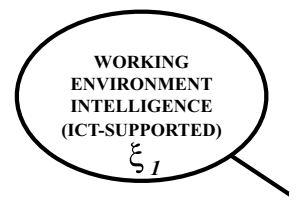

0.92
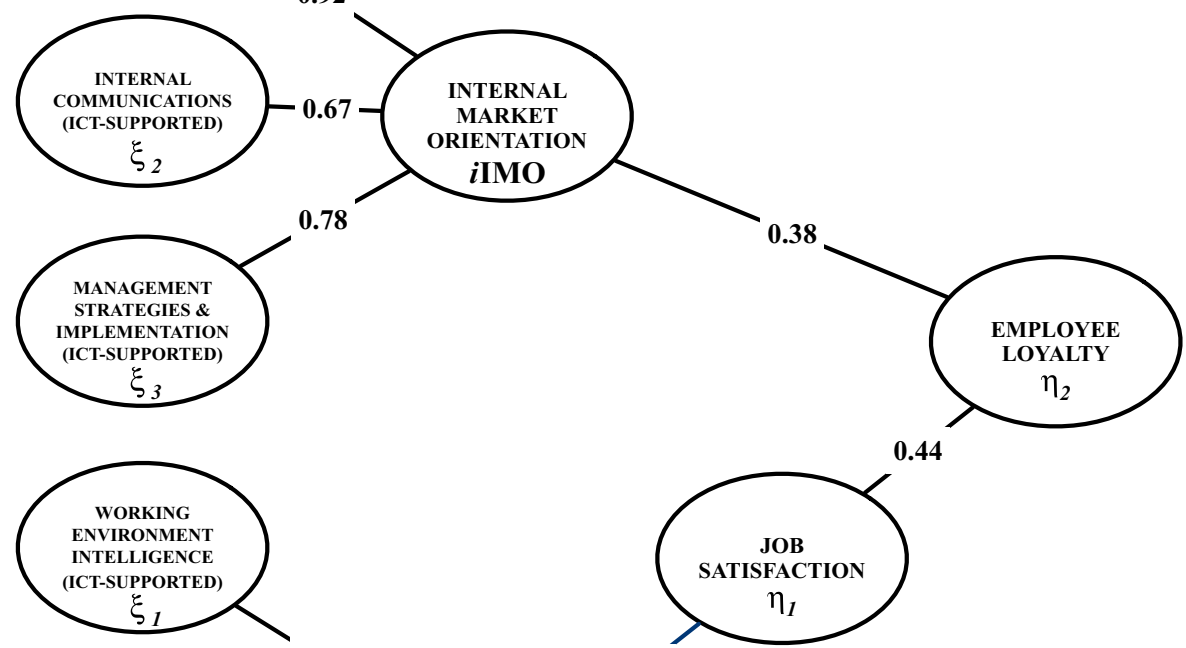

0.44

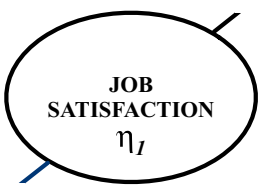

0.81

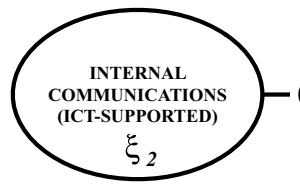

0.92

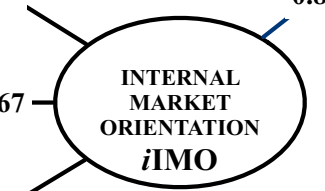

0.78

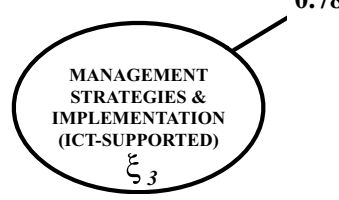

By gauging both the direct and indirect effect of $i \mathrm{IMO}$ antecedents using the chain rule, this study posits that the classical analysis of IMO using SEM can be enriched with instruments such as the derivative, which, on the one hand, allow additional conclusions to be drawn about the results and, on the other hand, offer a global vision of the interrelations between $i \mathrm{IMO}$ antecedents and consequences.

\section{Discussion}

\subsection{Implications for marketing theory}

This research raises several theoretical implications. First, we noted a paucity of extant research pertinent to internal marketing and IMO in the SME context, whereas SMEs' external market orientation has received reasonable amount of academic consideration (Länsiluoto et al., 2019). As SME business is an influential economic and social phenomenon important for society's development, we argue that IMO in SMEs should receive more consideration in the literature. In contrast to the prior research, this study sheds more light on 
IMO conceptualisation and suggests a practical framework of $i \mathrm{IMO}$ pursuant to the domain of SMEs.

Our findings manifest the plausibility of IMO operationalisation in SMEs. We posit that the IMO concept is generally applicable in SMEs. However, our research discerned several findings that are not in line with prior studies. In this regard, we determined the redundancy of personnel segmentation and training-development for IMO implementation in SMEs. These findings are in line with preceding studies that documented the issues with the application of these activities in the same settings (Achar, 2013).

Second, the present research introduces ICT as a novel IMO dimension that supports and drives its antecedents. The literature review pointed to a proliferation of ICT adoption in SMEs (Eze et al., 2019). Nevertheless, increasing SME digitalisation still has not received ample consideration in IMO literature. Addressing this noted gap in the theory, we mingled the IMO concept with ICT and employed pursuant measurement scales that were incorporated in all elements of the developed framework. Expert interviews supported the proposition of an ICT-IMO mix. The empirical results demonstrated that ICT are consistent with the $i \mathrm{IMO}$ framework.

Finally, this study contributes to the theory by positing the benefits that arise following $i$ IMO implementation in SMEs. The findings revealed significant positive $i \mathrm{IMO}$ effects on SMEs' organisational performance and supported the results of prior research (Lings and Greenley, 2009; Ruizalba et al., 2014). As such, iIMO drives the improvement of SME employees' satisfaction with their jobs, leading to employee loyalty. Furthermore, employee loyalty may facilitate a reduction in personnel turnover. The latter has been documented as a growing concern for SMEs (Emami et al., 2012). According to our study, iIMO both directly and indirectly improves employee loyalty, thus retaining them in their employing organisations. Thus, this study proposes a concept feasible to improve organisational performance that may consequently prevent costly staff turnover in SMEs.

\subsection{Managerial implications}

The completed study has meaningful implications for SME managers. While surveying SME employees, we noted their favourable perception of the $i \mathrm{IMO}$ concept. The concluding questionnaire section had an open field where employees could share their opinions and leave suggestions. Most of these text passages were relevant to wished-for improvements in internal communications, management care, and work-family balance. Interestingly enough, most comments highlighted the importance of the complex and systematic application of $i \mathrm{IMO}$ in their organisations as it would "deliver more sense to the job functions, improve performance, increase wages, and bring more wellbeing to a job routine". In conjunction with positive employees' comments, more importantly, our findings empirically confirmed the positive influence of $i \mathrm{IMO}$ on SME organisational performance. Thereby, it is essential to apply $i \mathrm{IMO}$ for the sake of organisational improvements in SMEs.

SME owners and business executives can benefit from the findings stemming from our study in several ways. First, internal labour market intelligence is an invaluable source of information on employees' needs, demands, and expectations. Our study has found that it is the most impactful $i \mathrm{IMO}$ antecedent on organisational performance. Intelligence is also useful for correct perception of the intrinsic working climate by discovering informal relationships between employees. It also helps to understand employees' feelings and intents. For this purpose, SMEs may intend to employ regular employee online surveys and virtual personal meetings in combination with the latest advances in Data Science, e.g. computer vision solutions that are even capable of employees emotional condition evaluation right at the working place.

Second, management can deliver their strategic decisions, keynotes, appraisals, etc. via internal communications that are also an important part of the $i$ IMO framework. Intranet, cloud computing, virtual co-working (e.g. Trello, Miro, Sutori and others) platforms are 
EJMBE 30,2 helpful in this respect. SME managers may also find internal communications practical for internal labour intelligence dissemination in SMEs when implementing $i \mathrm{IMO}$ in their organisations. Third, managers may use the best of intelligence in planning their responsive $i \mathrm{IMO}$ strategies. Intranet social media, messenger chat boards, social teamworking, online events, gamification can become useful technologies for iIMO implementation in SMEs.

SMEs are flexible and more innovative in comparison with larger organisations (Tsuji et al., 2018). SMEs can capitalise on this advantage in terms of faster, smoother, and more congruent $i \mathrm{IMO}$ adoption. To operationalise $i \mathrm{IMO}$ in their firms, first, SME management should realise that $i \mathrm{IMO}$ is a sophisticated strategic approach that entails routine commitment. Second, as a rule of thumb, it is essential to develop a workable plan, policies, schedule, and assign managers responsible for ICT-driven $i$ IMO deployment in the organisation. As our study evinces the significance of ICT in $i \mathrm{IMO}$, SME managers must enforce digital solutions deployment to support $i \mathrm{IMO}$ implementation. Finally, SME managers should acknowledge that $i \mathrm{IMO}$ requires resources. In this respect, SMEs may invest, for instance, in employee events as a part of internal communications, and training programmes as a part of responsive $i$ IMO strategy execution. Although the latter was neglected in the framework following the qualitative research phase, training-development should receive more consideration as it improves SME employees' performance (Achar, 2013).

Our findings point to the significant consequences of $i \mathrm{IMO}$, which determine the sense of its implementation in SMEs. In order to facilitate iIMO success, it is crucial to develop and execute a proper strategic plan of $i \mathrm{IMO}$ deployment that includes activities pursuant to internal labour market knowledge generation, internal communications, managerial care of employees, and support for work-family balance. If planned correctly and fully accomplished, $i$ IMO implementation will improve employee job satisfaction and, consequently, his/her loyalty to the employing SME. These achievements will signal the success of $i \mathrm{IMO}$ implementation.

\section{Limitations, future research, conclusions}

This study has a number of research limitations. First, we deem that the role and the essence of internal communications in IMO are ambiguous and misconceived in the literature. Under the conventional theory of market orientation, the pivotal role of internal communications includes the interdepartmental dissemination of external market intelligence (Kohli and Jaworski, 1990). In the realm of IMO, however, organisations collect information that may be sensitive and intimate to the employee; thus, its internal dissemination is somewhat questionable. Besides, other IMO constructs comprise similar interactive activities in their implementation (meetings, inductions, events, conventions, briefings). Thereby, internal communications should be likely embedded in the IMO management strategies. We engage in the dispute on the essence of internal communications in IMO and suggest the need to address this conceptual issue in future studies.

Second, after pretesting the research tools, we discarded personnel segmentation and training-development construct variables from the $i \mathrm{IMO}$ framework. We agree that given the size of SMEs, personnel segmentation may be negligible, but training-development is a different case. Interviewed experts pointed to a reluctance to invest in employee education by SMEs due to the limited availability of their financial resources. This judgement may be accepted as prior research concurs with it (Achar, 2013). Acknowledging the crucial role of training-development for $i \mathrm{IMO}$ in SMEs, we believe that it should receive an alternative approach. SME literature points to employee mentoring as a possible substitute for trainingdevelopment activities (Bozionelos et al., 2016). Under this proposition, we suggest that future researchers should consider employee mentoring instead of training-development as a variable for $i \mathrm{IMO}$ in the SME context. 
Third, we introduced ICT to the $i \mathrm{IMO}$ concept by blending them with first-order elements in this study, but they seemingly became "masked" within the conceptual framework. Grounded in the growing importance of ICT in SMEs, we deem that ICT should be set apart in conceptual models subjected to future research. In this sense, we recommend that future researchers consider ICT as an independent first-order latent factor that is incorporated in the second-order $i \mathrm{IMO}$ antecedent constructs. Moreover, prospective $i \mathrm{IMO}$ studies may also experiment with ICT as a standalone second-order $i \mathrm{IMO}$ antecedent construct.

Finally, as this research is the first known study relevant to IMO in the context of SMEs, it ICT and IMO impact on SME performance is not without generalisation issues. Little prior examination of this topic in the literature implied scant theoretical support, thus limitation for the present study. Also, as we investigated SMEs triangulated in a specific geography, namely Moscow, Russian Federation, this research setting combined with the aforementioned complications negatively impacts on theory generalisation further. Future research may address these issues and contribute to theory generalisation by scrutinising the proposed $i \mathrm{IMO}$ concept in different geographies, industries, and organisation sizes. Additionally, the literature reveals a profuse research stream dedicated to a comparative examination of family vs. non-family SMEs on various topics (Camisón et al., 2016). Prospective $i$ IMO studies may also consider this particular research facet.

We expect that the novel iIMO concept and our research findings will receive an awareness in both SME and marketing academic communities. We also encourage researchers to advance the theory through their respective contributions to $i \mathrm{IMO}$ concept conceptualisation, operationalisation and dissemination in the marketing literature. The authors believe that $i \mathrm{IMO}$ implementation has potential social implications given the number of people employed in SME organisations in many countries. In this respect, SME management should become aware that $i \mathrm{IMO}$ is not only capable of improving the organisational performance of SMEs, but simultaneously, the application of this concept can contribute to the well-being of society by ensuring that people are satisfied with their jobs.

\section{References}

Ab Wahab, N.Y., Mohamad, M., Yusuff, Y.Z. and Musa, R. (2020), “The importance of ICT adoption in manufacturing sector: an empirical evidence on SME business performance", International Journal of Supply Chain Management, Vol. 9 No. 2, pp. 268-272.

Achar, A. (2013), "Evaluation of training and development practices in SMEs: an empirical study", Prabandhan: Indian Journal of Management, Vol. 6 No. 4, p. 19.

AlBar, A.M. and Hoque, M.R. (2019), "Factors affecting the adoption of information and communication technology in small and medium enterprises: a perspective from rural Saudi Arabia”, Information Technology for Development, Vol. 25 No. 4, pp. 715-738.

Bendixen, M.T. and Sandler, M. (1995), "Converting verbal scales to interval scales using correspondence analysis", Management Dynamics: Contemporary Research, Summer, Vol. 4 No. 1 , pp. 31-49.

Berry, L.L. (1981), "The employee as customer”, Journal of Retail Banking, Vol. 3 No. 1, pp. 33-40.

Biemer, P. and Lyberg, L. (2003), Introduction to Survey Quality, Wiley, New Jersey.

Boukis, A. (2019), "Internal market orientation as a value creation mechanism", Journal of Services Marketing, Vol. 33 No. 2, pp. 233-244.

Bozionelos, N., Kostopoulos, K., Van der Heijden, B., Rousseau, D.M., Bozionelos, G., Hoyland, T. and Miao, R. (2016), "Employability and job performance as links in the relationship between mentoring receipt and career success", Group and Organization Management, Vol. 41 No. 2, pp. 135-171.

Camisón, C., Forés, B. and Puig-Denia, A. (2016), "Return on capital in Spanish tourism businesses: a comparative analysis of family vs non-family businesses", European Journal of Management and Business Economics, Vol. 25 No. 3, pp. 91-110. 
EJMBE 30,2

\section{6}

Cerqueirados, A.S., Mainardes, E.W. and de Oliveira, J.L.B. (2018), "Dimensions of internal market orientation related to job satisfaction and appreciation in Brazilian healthcare service", Journal of Health Management, Vol. 20 No. 3, pp. 291-308.

Chertchom, P., Yoshii, S., Charoenpong, P. and Yatsungnoen, T. (2019), "Strategic approach to adopt ICT in SMEs", TNI Journal of Engineering and Technology, Vol. 7 No. 1, pp. 73-80.

Chow, C.W.C., Lai, J.Y.M. and Loi, R. (2015), "Motivation of travel agents' customer service behavior and organizational citizenship behavior: the role of leader-member exchange and internal marketing orientation", Tourism Management, Vol. 48, pp. 362-369.

Churchill, G.A. (1979), “A paradigm for developing better measures of marketing constructs”, Journal of Marketing Research, Vol. 16 No. 1, p. 64.

Cuéllar-Molina, D., García-Cabrera, A.M. and de la Cruz Déniz-Déniz, M. (2019), "Emotional intelligence of the HR decision-maker and high-performance HR practices in SMEs", European Journal of Management and Business Economics, Vol. 28 No. 1, pp. 52-89.

Emami, R., Moradi, E., Idrus, D. and Almutairi, D.O. (2012), "Investigating the relationship between organizational learning culture, job satisfaction and turnover intention in SMEs", International Journal of Innovative Ideas, Vol. 12 No. 1, pp. 8-23.

Enders, C.K. and Bandalos, D.L. (2001), "The relative performance of full information maximum likelihood estimation for missing data in structural equation models", Structural Equation Modeling, Vol. 8 No. 3, pp. 430-459.

Eze, S.C., Chinedu-Eze, V.C. and Bello, A.O. (2019), "Determinants of dynamic process of emerging ICT adoption in SMEs - actor network theory perspective", Journal of Science and Technology Policy Management, Vol. 10 No. 1, pp. 2-34.

Fayol, H. (1918), Administration Lndustrielle et Générale, (in French), H. Dunod et E. Pinat, Paris, Vol. 2.

Foreman, S.K. and Money, A.H. (1995), "Internal marketing: concepts, measurement and application”, Journal of Marketing Management, Vol. 11 No. 8, pp. 755-768.

González-Porras, J.L., Ruiz-Alba, J.L., RodríguezMolina, M.A. and Guzmán-Parra, V.F. (2019), "International management of customer orientation", European Journal of International Management, doi: 10.1504/EJIM.2020.10022183.

Gounaris, S.P. (2006), "Internal-market orientation and its measurement", Journal of Business Research, Vol. 59 No. 4, pp. 432-448.

Gounaris, S. (2008), "Antecedents of internal marketing practice: some preliminary empirical evidence", International Journal of Service Industry Management, Vol. 19 No. 3, pp. 400-434.

Hackman, J.R. and Oldham, G.R. (1975), "Development of the job diagnostic survey", Journal of Applied Psychology, Vol. 60 No. 2, pp. 159-170.

Hair, J.F., Black, W.C., Babin, B.J. and Anderson, R.E. (2014), Multivariate Data Analysis: Pearson New International Edition, Pearson Education, Harlow.

Hales, C. (1994), "Internal marketing' as an approach to human resource management: a new perspective or A metaphor too far?", Human Resource Management Journal, Vol. 5 No. 1, pp. 50-71.

Hammond, P.J. and Sydsaeter, K. (2012), Essential Mathematics for Economic Analysis, 4th ed., Pearson Education, Harlow.

Hanclova, J., Rozehnal, P., Ministr, J. and Tvrdikova, M. (2015), “The determinants of IT adoption in SMEs in the Czech-polish border areas", Information Technology for Development, Vol. 21 No. 3, pp. $426-444$.

Hartline, M.D. and Ferrell, O.C. (1996), "The management of customer-contact service employees: an empirical investigation”, Journal of Marketing, Vol. 60 No. 4, p. 52.

Hult, G.T.M., Mena, J.A., Ferrell, O.C. and Ferrell, L. (2011), "Stakeholder marketing: a definition and conceptual framework", AMS Review, Vol. 1 No. 1, pp. 44-65. 
Jupp, V. (2015), "Purposive sampling", The SAGE Dictionary of Social Research Methods, SAGE Publications, London.

Karakara, A.A.-W. and Osabuohien, E. (2020), "ICT adoption, competition and innovation of informal firms in West Africa: a comparative study of Ghana and Nigeria", Journal of Enterprising Communities: People and Places in the Global Economy, Vol. 14 No. 3, pp. 397-414.

Kaur Sahi, G., Lonial, S., Gupta, M. and Seli, N. (2013), "Revisiting internal market orientation: a note", Journal of Services Marketing, Vol. 27 No. 5, pp. 385-403.

Kazakov, S. (2019), "Revisiting internal market orientation in family firms", European Journal of impact on SME performance Family Business, Vol. 9 No. 1, pp. 5-20.

Knox, S. and Freeman, C. (2006), "Measuring and managing employer brand image in the service industry”, Journal of Marketing Management, Vol. 22 Nos 7-8, pp. 695-716.

Kohli, A.K. and Jaworski, B.J. (1990), "Market orientation: the construct, research propositions, and managerial implications", Journal of Marketing, Vol. 54 No. 2, pp. 1-8.

Länsiluoto, A., Joensuu-Salo, S., Varamäki, E., Viljamaa, A. and Sorama, K. (2019), "Market orientation and performance measurement system adoption impact on performance in SMEs", Journal of Small Business Management, Vol. 57 No. 3, pp. 1027-1043.

Lings, I.N. and Greenley, G.E. (2009), "The impact of internal and external market orientations on firm performance", Journal of Strategic Marketing, Vol. 17 No. 1, pp. 41-53.

Lings, I.N. (2000), "Internal marketing and supply chain management", Journal of Services Marketing, Vol. 14 No. 1, pp. 27-43.

Lings, I.N. (2004), "Internal market orientation - construct and consequences", Journal of Business Research, Vol. 57 No. 4, pp. 405-413.

Liu, H.-M. and Yang, H.F. (2020), "Network resource meets organizational agility", Management Decision, Vol. 58 No. 1, pp. 58-75.

Maseda, A., Iturralde, T., Aparicio, G., Boulkeroua, L. and Cooper, S. (2019), "Family board ownership, generational involvement and performance in family SMEs", European Journal of Management and Business Economics, Vol. 28 No. 3, pp. 285-300.

Matzler, K. and Renzl, B. (2006), "The relationship between interpersonal trust, employee satisfaction, and employee loyalty", Total Quality Management and Business Excellence, Vol. 17 No. 10, pp. 1261-1271.

Mayo, E. (1933), The Human Problems of an Industrial Civilization, The Macmillan Company, New York.

Modi, P. and Sahi, G.K. (2018), "The meaning and relevance of internal market orientation in nonprofit organisations", Service Industries Journal, Vol. 38 Nos 5-6, pp. 303-320.

Mohrw-Jackson, I. (1991), "Broadening the market orientation: an added focus on internal customers", Human Resource Management, Vol. 30 No. 4, pp. 455-467.

Mueller, C.W., Wallace, J.E. and Price, J.L. (1992), "Employee commitment: resolving some issues", Work and Occupations, Vol. 19 No. 3, pp. 211-236.

Narver, J.C. and Slater, S.F. (1990), "The effect of a market orientation on business profitability", Journal of Marketing, Vol. 54 No. 4, pp. 20-35.

Noori, R., Alias, M. and Rosdi, I. (2017), "Understanding the drivers for innovative work behavior in Malaysian SMEs", 5th International Conference on Innovation and Entrepreneurship ICIE 2017, pp. 110-117.

Peteraf, M.A. (1993), “The cornerstones of competitive advantage: a resource-based view", Strategic Management Journal, Vol. 14 No. 3, pp. 179-191.

Piercy, N. (1995), "Customer satisfaction and the internal market: marketing our customers to our employees", Journal of Marketing Practice: Applied Marketing Science, Vol. 1 No. 1, pp. 22-44. 
EJMBE 30,2

Piercy, N.F. (2009), "Strategic relationships between boundary-spanning functions: aligning customer relationship management with supplier relationship management”, Industrial Marketing Management, Vol. 38 No. 8, pp. 857-864.

Pitt, L.F. and Foreman, S.K. (1999), "Internal marketing role in organizations", Journal of Business Research, Vol. 44 No. 1, pp. 25-36.

Rafiq, M. and Ahmed, P.K. (1998), "A customer-oriented framework for empowering service employees”, Journal of Services Marketing, Vol. 12 No. 5, pp. 379-396.

Raissi, N. and Matoussi, H. (2020), "The influence of ICT adoption on the development of managerial modes of consulting firms in France", ICT for an Inclusive World, Springer, Cham, pp. 37-54.

Raju, P.S., Lonial, S.C. and Crum, M.D. (2011), "Market orientation in the context of SMEs: a conceptual framework", Journal of Business Research, Vol. 64 No. 12, pp. 1320-1326.

Riemer, K. and Taing, S. (2009), "Unified communications", Business and Information Systems Engineering, Vol. 1 No. 4, pp. 326-330.

Rincón Díaz, C.A. and Albors Garrigós, J. (2017), "Research and technology organizations' mobilizers of the regional environment", European Journal of Management and Business Economics, Vol. 26 No. 2, pp. 180-198.

Ruizalba, J.L. and Vallespín, M. (2014), "Empirical analysis of the constituent factors of internal marketing orientation at Spanish hotels", Tourism and Management Studies, Vol. 10, pp. 151-157.

Ruizalba, J.L., Bermúdez-González, G., Rodríguez-Molina, M.A. and Blanca, M.J. (2014), "Internal market orientation: an empirical research in hotel sector", International Journal of Hospitality Management, Vol. 38, pp. 11-19.

Ruizalba, J., Soares, A., Vallespín Arán, M. and González Porras, J.L. (2016), "Internal market orientation and work-family balance in family businesses", European Journal of Family Business, Vol. 6 No. 1, pp. 46-53.

Sasser, W.E. and Arbeit, S.P. (1976), "Selling jobs in the service sector", Business Horizons, Vol. 19 No. 3, pp. 77-100.

Tansuhaj, P., Randall, D. and McCullough, J. (1988), “A services marketing management model: integrating internal and external marketing functions", Journal of Services Marketing, Vol. 2 No. 1 , pp. 31-38.

Teddlie, C. and Yu, F. (2007), "Mixed methods sampling", Journal of Mixed Methods Research, Vol. 1 No. 1, pp. 77-100.

Tortosa, V., Moliner, M.A. and Sánchez, J. (2009), "Internal market orientation and its influence on organisational performance", European Journal of Marketing, Vol. 43 Nos 11/12, pp. 1435-1456.

Tsuji, M., Ueki, Y., Shigeno, H., Idota, H. and Bunno, T. (2018), "R\&D and non-R\&D in the innovation process among firms in ASEAN countries", European Journal of Management and Business Economics, Vol. 27 No. 2, pp. 198-214.

Varey, R.J. (1995), "A model of internal marketing for building and sustaining a competitive service advantage", Journal of Marketing Management, Vol. 11 Nos 1-3, pp. 41-54.

Westland, J.C. (2015), Structural Equation Models: From Paths to Networks, Springer, New York, NY.

Yu, Q., Yen, D.A., Barnes, B.R. and Huang, Y.-A. (2019), "Enhancing firm performance through internal market orientation and employee organizational commitment", International Journal of Human Resource Management, Vol. 30 No. 6, pp. 964-987.

\section{Further reading}

Ambrosio, L. and Dal Maso, G. (1990), "A general chain rule for distributional derivatives", Proceedings of the American Mathematical Society, Vol. 108 No. 3, pp. 691-702. 
Employees classification into well-defined groups according to their individual needs

Policies development considers effects on different segments of employees with similar needs and characteristics

All employees are treated in exactly the same way, regardless of their needs and individual characteristics

Labour Market Research (1st order construct)

Management is aware of open positions in the external labour market that can appeal to employees

Organisation continuously monitors remuneration packages and fringe benefits offered by organisations in the external labour market

Management is aware of the remuneration packages and fringe benefits offered by its competitors

ICTs Utilisation in Market Intelligence (1st order construct)

Organisation utilises electronic means for internal surveys

Organisation uses the latest technologies (Data Science, AI, Machine Learning) for labour market data collection

Organisation employs a specialised analyst for external and internal HR and labour market analysis

Management strategies and implementation (ICT-supported)

Management Concern and Care (1st order construct)

Supervisors invest resources (time and/or money) where needed in order to satisfy the specific needs or requirements of employees

The needs of employees are taken seriously by managers, and policies are

developed with the aim of satisfying these needs

Supervisors are clearly geared toward solving any problems that employees may have and providing them with the support they need to perform their job well Supervisors are genuinely interested in employees as people, regardless of how well they perform their job or the results they achieve

Supervisors are genuinely interested in hearing about and understanding their employees' feelings insofar as these affect their work

Training and development (1st order construct)

Prior to implementing a new service, or modifying an existing one, employees are given extensive training in relation to the change and how it will affect their way of working

The company systematically and continuously organizes training seminars so that employees can develop their skills

If employee is moved to a new task or department, his/her new supervisor will personally provide training in relation to the new role

Work-life balance (1st order construct)

Supervisors understand the family needs of employees

Supervisors support employees so that they can combine their work and family commitments

(continued)

Table A1.

iIMO framework scales sheet 


\section{EJMBE} 30,2

150
Scales (manifest variables)

Reference

Employees are able to find a balance between work and family life

Remuneration policies: salary and incentives (1st order construct)

Remuneration raise and career advancement depends solely on employee

performance

Remuneration raise and career advancement is grounded on regular employee

evaluation with the help of KPIs

Remuneration raise and career advancement is linked to years of service,

educational level increase, professional communities memberships etc

Job essence and functions (1st order construct)

Job description is realistic to attain employee KPIs

Employee assumes assignments solely upon his/her agreement

Employee assignments, functions and KPIs endorse his/her career advancement

ICT in management strategies and implementation (1st order construct)

Hanclova et al. (2015)

Organisation runs an electronic service where employees may obtain an

information on their evaluation scores, remuneration, benefits and other relevant

data of employment

Employee receives training and does not have difficulties with connection to intranet services, corporate email etc

Organisation runs special IT services, provides specialised software etc. (e.g.

Salesforce, corporate messengers, CRM) for successful job implementation in every business function

\section{STRUCTURAL MODEL}

Working Environment Intelligence (2d order construct)

Interior Communications (2d order construct)

Supervisors communicate with employees and listen to what employees have to say

Ruizalba et al. (2014)

about their work, any problems they might have, and the suggestions they put

forward

Employees may report a personal problem that has a negative effect on their performance, organisation encourages employees to talk to about it with supervisor Supervisors are always available to meet personally with an employee if such a meeting is requested

Supervisors spend time with employees, explaining them the company's objectives and how these objectives affect what the company expects from each individual employee

Corporate events (parties, team building workshops) are beneficial for the company

and valued by employees

Employees are aware of what is going on in the organisation

Organisation actively utilises electronic means (email, intranet, corporate

messengers) of internal communications

Management strategies and implementation (ICT-supported)

\section{STRUCTURAL MODEL}

(ICT-supported) Internal Market Orientation (3d order construct)

Job satisfaction (1st order construct)

Employee perceived satisfaction with the relationship with his/her respective supervisors

Employee perceived satisfaction with the support received from the organisation 
STRUCTURAL MODEL

Employee perceived satisfaction with the career opportunities I have in this company

Employee loyalty (1st order construct)

This company deserves that employees do their best at work

Employees feel the emotional tie to the company

Employee would feel guilt if he/she had to leave the organisation right now

Employee believe that organisation is widely regarded as a highly

prestigious employer and can be recommended to friends
ICT and IMO impact on SME

performance

Knox and Freeman (2006)

\begin{abstract}
About the authors
Sergey Kazakov (Doctor of Economic Sciences - in accord with Russian academic ranking) is Associate Professor at Company Marketing Department, School of Business Administration of the National Research University Higher School of Economics (NRU HSE), Moscow, Russia. He has 30 years of professional experience in sales, marketing, international management and consulting. In his academic career, Dr. Kazakov has liaised with ten universities and business schools for teaching and theses supervising. His list of publications totals 95 journal articles, books, book chapters, monographs and conference papers in the areas of Marketing, Sales, Hospitality and Tourism Management. He was honoured with the "Best Professor of the year" award by NRU HSE in 2019. Sergey Kazakov is the corresponding author and can be contacted at: skazakov@hse.ru

José L. Ruiz-Alba (Ph.D., EMBA, PDG-IESE, SFHEA) is Research Leader of the School of Management and Marketing of the University of Westminster and Senior Lecturer in Marketing (London, UK). He has more than 30 years of professional experience in different service areas: Law firm; Business Schools; Universities; Consultancy and Franchised Group of Quick Service Restaurants. He has broad teaching experience in more than 15 Universities. He has written over 60 academic journal articles, book chapters and conference papers. Member of Editorial Advisory Board of the Journal of Business and Industrial Marketing and Associate Editor of the International Journal of Internet Marketing and Advertising. He has received the best paper award from the Spring Servitization Conference (Manchester, May, 2016). He was Co-chair of the International Conference CBIM2018 and Guest Editor of a Special Issue for the Journal of Business and Industrial Marketing

María M. Muñoz (Ph.D.) is Vice-Dean of Research at the Faculty of Commerce and Management and Senior Lecturer of the Department of Applied Economics (Mathematics) at the University of Málaga (Spain). Currently she teaches quantitative methods applied to Economy and Business. She has published several research papers in scientific journal, such as European Journal of Operational Research, TOP, Journal of Optimization Theory and Applications, TOP, OR Spectrum and Annals of Tourism Research), three books, and several conference proceedings, in the area of areas of Multicriteria Analysis, Stochastic Programming, with theoretical and applied contributions. She has participated in eighteen research projects. Her main research interests are multicriteria decision analysis, economic applications of optimization methods and stochastic programming.
\end{abstract}

For instructions on how to order reprints of this article, please visit our website:

www.emeraldgrouppublishing.com/licensing/reprints.htm

Or contact us for further details: permissions@emeraldinsight.com 